International Journal of Science and Education 4(2), 54-66

Uluslararası Bilim ve Eğitim Dergisi, 4(2), 54-66

DOI: 10.47477/ubed.929621

Makale Türü: Derleme

Başvuru Tarihi: 28.04.2021

Yayına Kabul Tarihi: 19.08.2021

\title{
Risk Altındaki Çocuklarla Yürütülen Grup Çalışmaları
}

\author{
Özden TURGUT ${ }^{* 1}$
}

Öz

Çocukların karşılaştıkları gelişimsel zorluklarla daha işlevsel başa çıkabilmeleri için sunulabilecek psikolojik destek türlerinden biri grupla psikolojik danışmadır. Grupla psikolojik danışma, risk altındaki çocuklar söz konusu olduğunda, çocukların, içinde bulundukları durumda duygularının farkına varmaları ve ifade etmelerine zemin hazırlamaktadır. Ayrıca daha kısa süren grup müdahaleleri de bulunmaktadır. Risk altındaki çocuklar, ev içi şiddete tanık olan ve/veya maruz kalan, ihmal ve istismara uğrayan, suça sürüklenen, kayıp ve yas sürecindeki çocukları içinde alan geniş kapsamlı bir kavramdır. Bu çalışmada, risk altındaki çocuklarla yürütülen grup çalışmaları incelenmiş ve risk altındaki çocuklar, ihmal ve istismar mağduru çocuklar, kayıp ve yas sürecindeki çocuklar ile suça sürüklenen çocukları içerecek şekilde sınırlandırılmıştır.

Anahtar Kelimeler: Grup çalışması, ihmal ve istismar, kayıp ve yas, suça sürüklenen çocuk

\section{Group Interventions With Children At-Risk}

\begin{abstract}
Group counseling is one of the support ways for children to cope with the developmental challenges they have faced. Group counseling is also functional for the children-at-risk to realize and express their own feelings. Also there are different group interventions that aim to strengthen the children at-risk. Children-at-risk is a broad concept that implicates the children who have experienced domestic violence, abuse and neglect, loss and grief or juvenile delinquency. The concept "children at risk" is limited into three groups of children in this review: The children who have witnessed/experienced abuse and neglect, who have experienced loss and grief and the children who are juvenile delinquents. This study has examined the group interventions that have been run with the children-at-risk.
\end{abstract}

Key Words: Group intervention, neglect and abuse, loss and grief, juvenile delinquency 


\section{Giriş}

Birçok çocuk, sınav kaygısı, okul başarısızlığı, sosyal yalıtılmışlık (isolation) ve reddedilme yaşamakta ya da akran zorbalığına maruz kalmaktadır. Ayrıca, ailesinin parçalanmasına tanık olma, ihmal ve istismara maruz kalma, ölüm, savaş ve afetler, çocukların işlevselliğini etkileyen stres kaynaklarından bazılarıdır (Amerikan Psikiyatri Derneği, 2000). Çocuklarla yürütülen grup çalışmalarında, çocuk ve ergenlerin bu sorunlarla başa çıkmalarını kolaylaştırma üzerinde çalışılmaktadır. Dolayısıyla, çocuk ve ergenlerle yürütülen grup çalışmaları, çocukların kişisel ve kişiler arası gereksinim ve çatışmaları üzerinde durmayı amaçlamaktadır (Dinkmeyer ve Muro, 1979). Grupla psikolojik danışma sayesinde çocuklara kabul edildikleri, cesaretlendirildikleri, yeni davranışları güven içinde deneyimledikleri, duyguları üzerinde konuşabildikleri ve çalışabildikleri bir ortam sağlanabilmektedir (Morganett, 1990).

Çocuklarla yürütülen grup çalışmaları, temel olarak üç şekilde gerçekleştirilmektedir: Eğitimsel / rehberlik grupları, danışma grupları ve terapi grupları. Eğitimsel gruplar, daha çok normal koşullardaki çocuklara sosyal beceriler konusunda destek sağlamayı amaçlarken, danışma grupları, çocuklara, duygularını ifade edebilecekleri ortam sayesinde yapıcı geribildirimle iç görülerini geliştirebilme şansı vermektedir. Terapi grupları ise ileri düzeyde uyum ya da davranış bozuklukları olan çocuklarla çalışmayı hedeflemektedir (Shechtman, 2002).

Çocuklarla yürütülen gruplarda dört terapötik faktör bulunmaktadır: (a) duygusal farkındalık-iç görü, (b) ilişki-iklimi, (c) diğerine karşı kendilik odağı, (d) problem tanımlama-değişim. Duygusal farkındalık, farkındalık ve iç görü kazanmayla bağlantılı güçlü duygulanımları kapsamaktadır. İlişki-iklimi, gruptaki ilişkilerin oluşumu ve sürdürülmesi iken, diğerine karşı kendilik odağı, çocuğun diğerlerinden öğrenmesini ifade etmektedir. Problem tanımlama-değişim ise, problemleri çözme ve davranışta değişim anlamına gelmektedir (Shechtman ve Gluk, 2005). Bu derleme çalışmasında risk altındaki çocuklarla yürütülen grup çalışmaları ele alınmaktadır. Çalışma alan yazın taraması yapılarak gerçekleştirilmiştir.

\section{Risk Altındaki Çocuklar}

Risk altındaki çocuklar, odaklanılan konuya göre kapsamı değişebilen bir kavramdır. Örneğin, erken yaşlarda sigara ve alkol kullanmaya başlayan çocuklar (Staff, Maggs, Cundiff ve Evans-Polce, 2016), saldırgan davranışları yüksek düzeyde olan çocuklar (Cui, Colasante, Malti, Ribeaud ve Eisner, 2016), akran zorbalığına maruz kalan çocuklar (Elledge, Elledge, Newgent ve Cavell, 2016), risk altındaki çocuklara örnek olarak gösterilebilir. Aynı zamanda, ev içi şiddete tanıklık eden çocuklar (Thompson, 2011), ihmal ve istismar mağduru olan çocuklar (Wanlass, Moreno ve Thomson, 2006; Platt, 2016), anne/babası cezaevinde olan çocuklar (Lopez ve Bhat, 2007), kayıp ve yas sürecindeki çocuklar (Finn, 2003; Samide ve Stockton, 2002) da risk altındaki çocuklar olarak nitelendirilebilir. $\mathrm{Bu}$ çalışma kapsamında, ihmal ve istismar mağduru çocuklar, kayıp ve yas sürecindeki çocuklar ve suça sürüklenen çocuklara odaklanılarak, risk altındaki çocuklarla gerçekleştirilen grup çalışmaları incelenmektedir.

\section{İhmal ve İstismar Mağduru Çocuklar}

Çocuk ihmal ve istismarı, çocukla bakıcısı arasında, çocuğun fiziksel ve/veya gelişimsel durumuna yansıyan ve bir kaza sonucu ortaya çıkmayan etkileşim veya etkileşim eksikliğidir (Lynch, 1999). Çocuk, fiziksel ve/veya duygusal yönden ihmal edilmiş olabilir; fiziksel, duygusal ya da cinsel açıdan istismar edilmiş olabilir. Çocukluğunda yetersiz ebeveynlik eşliğinde, çok sert cezalarla karşılaşmış, yeterli düzeyde rehberlik edilmemiş ve ebeveyn desteğini sınırlı alabilmiş bireylerle yapılan çalışmalarda davranım bozukluğu ve suçluluk riskinin artmış olduğu bildirilmektedir (Levenson ve Grady, 2016). Dolayısıyla, çocuğu ihmal ve/veya istismar eden yetişkinin patolojik özellikleri olabileceği ifade edilebilir. Bunun yanında, çocuğuna yeterli desteği veremeyen 
ebeveynlerin, kurdukları evlilik birliğinin ev içi şiddet davranışlarını içermesi ve çocuğun da bu şiddete tanık olması olanak dâhilindedir.

Çocuk ihmali, genel olarak fiziksel ya da cinsel istismara göre daha az belirgindir, daha zor ölçülebilmekte ve tanımlanabilmektedir. Yapılan çalışmalar, ihmal edilmiş çocukların, fiziksel ve gelişimsel gerilik ile özellikle konuşma ve dil gelişimi açısından bilişsel hasar gösterdiğini; ayrıca, insan ilişkilerinde bağlanma yeterliklerinin zedelendiğini ortaya koymuştur (Green, 2000).

Çocuk cinsel istismarı, fiziksel teması içerebilmekte veya içermeyebilmektedir. Çocuk cinsel istismarı mağdurlarının yaş düzeylerine göre verdikleri tepkilerin değişebildiği, ancak her yaş düzeyinde verilen ortak tepkilerin, kâbus görme, depresyon, geri çekilme davranışı (withdrawal), saldırganlık, gerileyici davranış (regression) ve okul/öğrenme zorlukları olduğu bildirilmiştir (Kendall-Tackett, Williams ve Finkelhor, 1993). Ensest, bir çocuk ile onun yakın bir akrabası arasındaki cinsel etkinlik olarak tanımlanmaktadır. Ensest mağduru olan çocuklar, aile dışı cinsel istismar mağdurlarına kıyasla istismar hakkında çarpıtılmış bilişler geliştirmeye daha açı olabilmektedirler. Bu durum, failin, istismarı "normal", sevgi dolu bir aile etkileşimi olarak sunmasıyla ilişkili olabilmektedir. Bazı mağdurlar, faile karşı çelişik duygular geliştirebilmekte ve kendilerini suçlayabilmektedir (Cohen ve Mannarino, 2000). Bu noktada mağdurun arada kalmışlığı, destek arayışının sonuçsuz kalması ile ilgili olabilmektedir. Özellikle ev içi şiddetin yoğun olduğu bir ailede bakım ve destek ararken büyük kardeş istismarının meydana gelebileceği öne sürülmekte (Brennan, 2006); ev içi şiddetin hüküm sürdüğ̈̈ bir ailede, ebeveynlerin çocuğu birbirlerini incitmek ve kontrol etmek için bir araç olarak kullanabildiği belirtilmektedir. Örneğin, McCloskey, Figueredo ve Koss'un (1995) çalışmasında, annesinin şiddet görmesinin, bir çocuk için ensest açısından ciddi bir risk faktörü olduğu ileri sürülmüştür.

Ev içi şiddete tanık olan çocuklar da, ebeveynleri tarafından istismar edilmiş çocuklarla benzer şekilde uyum zorlukları göstermektedir (Jaffe, Wolfe, Wilson ve Zak, 1986). Dodd (2009), hamileliğin, yani çocuğun henüz anne karnında olduğu dönemin, genellikle ev içi şiddetin daha da arttı̆̆ bir dönem olduğunu bildirmektedir.

Şiddete tanık olan her çocuğun farklı bir başa çıkma biçimi geliştirdiği belirtilmektedir. Kimisi kendisini güvende hissetmek için çevresindekilere saldırgan davranırken, bazıları geri çekilmektedir (Wagar ve Rodway, 1995). Şiddet içeren davranışları olan ebeveynlerin çocuklarının, a) "çatışma, şiddet ile çözülür", b) "aile üyelerinin etkileşimi şiddet içerir", c) "şiddet, bir stres yönetimi biçimi olarak onaylanır" düşüncelerini öğrendikleri ileri sürülmektedir (Jaffe, Wilson ve Wolfe, 1986). Şiddet döngüsüne maruz kalmanın, bireyin şiddet içeren ve istismar edici ilişkilere dâhil olma riskini artırdığı belirtilmiştir (Kot, Landreth ve Giordano, 1998). Bununla aynı doğrultuda dikkat çeken bulgulardan biri de, ihmal ve istismar mağduru çocukların, çeşitli ihtiyaçlarına yanıt vermeyen ortamlarda büyümelerinin, çarpıtılmış bilişsel şemalara, sınır ihlallerine yol açmasıyla (Chakhssi, deRuiter ve Bernstein, 2013), bu çocukların cinsel suç işleyen bir yetişkine dönüşmesi riskinin anlamlı bir şekilde arttığı gösterilmiştir (Levenson ve Grady, 2016).

\section{İhmal ve İstismar Mağduru Çocuklarla Yürütülen Gruplar}

İstismar yaşantısı ile ilgili grup çalışması yapılmasının en önemli nedeni, öyküyü anlatma eylemi sonlandığında, travmatik yaşantının gerçekten geçmişe ait hale gelmesidir (Herman, 1992). Bu noktada grupla danışmanın bireysel danışmaya kıyasla neden ön planda olabileceği sorusu ortaya çıkabilir. Cinsel istismar mağduru olan çocuklar özelinde bakıldığında, çocuklar, güvenlerinin kötüye kullanılabilir, güçlerine karşı gelinebilir olduğu yaşantılar geçirdiği için bireysel terapiye kuşkuyla bakmaları olasıdır. Grup terapisinde ise duygusal ihtiyaçlar, bireysel terapinin duygusal yoğunluğu olmaksızın karşılanabilmektedir. Ayrıca grup terapisindeki eşitlikçi ilişki ve etkileşimlere olan vurgu, bireysel terapideki güç asimetrisinin tam tersi niteliktedir (deYoung ve Corbin, 1994).

Wanlass, Moreno ve Thomson (2006), ihmal ve istismar mağduru olan ergenlerle grup yürüten liderlerin, kaotik kişiler arası etkileşimler, yoğun duygu durum, sınır meseleleri, grup savunmaları ile transferans ve karşıt transferans tepkilerini yönetme zorunlulukları olduğunu belirtmiştir. Yazarlar, grubun hedeflerini dört başlık altında toplamıştır: (1) Zor bir dönemden geçen 
grup üyelerine duygusal destek sağlamak, (2) Üyelere, kendi mağdur olma durumları üzerinde çalışabilecekleri bir ortam sağlamak, (3) Normal gelişimsel meseleleri (örn. okul, akran meseleleri, ilgiler) tartışabilecekleri bir ortam sağlamak, (4) Psikolojik sağlamlıkla ilişkili becerileri (örn. özsaygıyı, kişilerarası destekleri ve uyum sağlayıı başa çıkma stratejileri ) geliştirmek.

İhmal ve istismar mağduru çocuklarla yürütülen gruplarda, üyelerin karmaşık duyguları, grup lideri açısından başa çıkılması kolay olmayan sorunlar meydana getirebilmektedir. Örneğin, güvenilir bir baba figürü iken kendisine cinsel istismarda bulunan büyükbabasını, durum ortaya çıktığında "kaybeden" Lisa, aniden aile kavramı çatırdamış, iyi/kötü arasındaki ayrım bulanıklaşmış ve dünyayı anlamsız olarak algılarken başladığı grubu, bu duygu durumun etkisi altında algılamakta, "aptal" gruptan hoşlanmamakta, ama perşembe akşamları yapacak daha iyi bir şeyi olmadığından gruba gelmektedir. Bu grupları yürüten liderler açısından dikkat edilecek en önemli noktalardan biri, üyelerin belirli duygularıyla ilişkili uyarıcılardan kaçınmaları ya da bu duygulara bir sel halinde kapılmalarıdır. Grup lideri, böyle bir durumda, kaçınma ile kapılma arasında bir denge bulmaya gayret göstermelidir. Lider, grup sırasında, kaygı yaratan uyarıcılar söz konusu olduğunda konuyu değiştirme davranışı ile de karşılaşılabilmektedir. Bir üye, terapiste terliklerini nereden aldığını sorduğunda, terapist, bu sorunun tam da başka bir üye, (zanlı olan) babasını mahkeme salonunun dışında gördüğünü anlattıktan sonra geldiğini fark eder. Terapist bu noktada, üyeye, diğer üyenin anlattıkları ile ne hissettiğini sorabilir (Wanlass, Moreno ve Thomson, 2006).

Cinsel istismar mağdurlarıyla yürütülen gruplar için vurgulanan bir başka husus da, anlatılan hiçbir öykünün grup tarafından olayın ciddiyet derecesi ya da üyenin zarar görme durumuna göre derecelendirilip sıralanmaması gerektiğidir. Bunun nedeni, her bir öykünün, onu paylaşan kişinin biricik yaşantısı olmasıdır. Bu gruplarda terapistin işlevi yalnızca dinlemek değil, aynı zamanda üyelerin dili kullanmasını kolaylaştırmak, yanıtları normalleştirmek, duygusal yükü paylaşmak ve cinsel istismar yaşantısının, üyenin haysiyet ve değerini onaylayan yeni bir yorumunu inşa etmektir (deYoung ve Corbin, 1994).

Ev içi şiddete dolaylı ya da doğrudan maruz kalan 6-7 yaşlarındaki çocuklara yönelik yürütülen bir grup, dört aşamadan oluşmuştur (Thompson, 2011):

(1) Araştırma ve oryantasyon: Bu aşamada, grup üyeleri arasında yakınlık sınırlıdır; oyuncakları sahiplenici bir tutumları vardır. Paylaşım mevcut olsa da nadirdir.

(2) Güçlerini karşılaştırma ve kısa kendini açmalarla sınama: Bu aşamada, grup üyeleri, hem diğer üyeleri tanımaya çalışmakta, hem de eşzamanlı olarak diğer üyeler ile kendilerini kiyaslamaktadır.

(3) Bütünlük ve risk alma: Daha derin kendini açma davranışları gözlemlenir.

(4) Grubun sonlandırılması ve kutlamalar: Üyeler, grubun bitiyor olmasıyla bağlantılı duygularını paylaşır ve çeşitli ikramlar eşliğinde eğlenirler.

Örnek olarak sunulan bu grup yaşantısı, oyun terapisi yöntemi ile inşa edilmiş ve bu sayede katılımcı çocuklar oyun terapisinin iyileştirici gücü eşliğinde çalışmıştır. Ev içi şiddete tanıklık etmiş çocuklarla yürütülen grup oyun terapisinde, çocuğun güvenlik duygusunun zedelendiği (Campbell ve Lewandski, 1997), kendisini çevresel koşullar karşısında güçsüz ve kırılgan hissettiği için, oyun terapisiyle, kişisel kontrol ile bağlantılı duygulara ulaşabilmesi ve başa çıkma becerilerini içselleştirebilmesi hedeflenmektedir (Landreth, 1991).

Ev içi şiddete maruz kalan anneler ve çocuklarıyla yürütülen başka bir grup çalışmasında ise odak noktası, şiddete maruz kalan annenin, çoğu zaman depresif, şaşkın ve duygusal olarak tükenmiş olması nedeniyle, çocuğuna destek olmakta güçlük çekmesidir. Bu grup, annenin çocuğu için duygusal anlamda ulaşılabilir, bakım verebilen ve duyarlı olmaya devam edebilen bir figür olmasını sağlamayı hedeflemektedir. Bu noktada, anne, kendi travmatik yaşantısına rağmen, çocuğu için duygusal anlamda "orada" olma, "hayatta kalma" becerisini ona öğreten ve şiddete karşı kendini korurken şiddet içermeyen tepki vermeyi becerebilen model olma konularında güçlendirilmek istenmektedir (Dodd, 2009).

Grusznski, Brink ve Edleson (1988) on hafta süren ve esnek yapılı bir grup çalışması oluşturmuştur. Başlangıçta, üyelerin kendilerini açması odak noktası olmaktan nispeten uzaktır; her 
oturum bir etkinlik ile başlamaktadır. Birkaç oturum sonrasında, odak, daha kişisel içeriğe doğru evrilmekte; 3. ya da 4. oturum ile birlikte, ev içi şiddet konusu tanıtılmaktadır. Yaklaşık olarak 4. oturumdan itibaren şu konular ve beceriler sistematik olarak sunulmaktadır:

(1) Maruz kaldığı/tanıklık ettiği şiddette sorumluluğu olmadı̆̆ını fark etme: Grup üyelerinin bir etkinliği, "bu benim hatam değil!" biçiminde şarkı söylemektir. Ergen üyeleri olan gruplarda ise, olay zincirinin incelenmesi ve kişisel sorumluluklarının olmadığına ilişkin farkındalık kazandiran bir etkinlik uygulanabilmektedir.

(2) Utanç ve yalıtılma: Şiddetin yaşandığı ailelerde örtük bir kural, "sırrı tutabilmek"tir. Bu konuda yapılabilecek bir etkinlik, her üyenin kendi ailesinin portresini çizip ailesini diğer üyelere tanıtması şeklindedir. Bu, aileyi gölgeler arasından alıp ışığa getirebilir. Sırlarla ilgili yapılabilecek diğer bir etkinlik de, eğlenceli sırlar ile incitici sırları listelemek ve aralarındaki farklılıkları tartışmaktır.

(3) Korunma planlaması: İkinci ya da üçüncü oturumda, genel bir korunma planlaması üyelere tanitılır. Sonraki bir oturumda, üyelerin kendileri şiddet tehdidi ile karşılaştıklarında kullanabilecekleri bir korunma planı geliştirilmesi üzerinde çalışılır. Daha küçük üyelerin bulunduğu gruplarda, diğer çocukların nasıl güvende kaldıklarını anlatan öyküler ya da örnekler üzerinde konuşulur.

(4) Duygularn ifade edilmesi: Bu konuda ilk adım, üyelerin bir dizi duyguyu tanımayı öğrenmesidir. Her hafta üyelerden, belli bir duyguyu uyandıran bir örnek olay getirmeleri istenebilir. Duyguları tanıma ve ifade etme becerisinin geliştirilmesi hedefleniyor olsa da, duygularını ifade etmek her üye için güvenli bir davranış olmayabilir. Dolayısıyla grup liderleri, ev içindeki koşulların dikkate alınmasına vurgu yapar.

(5) Çatışma çözme: Bu konuda, iki ayrı yol olduğu, bir yolun karşı tarafı anlamaya çalışmak, diğer yolun ise şiddet kullanma olduğu ifade edilir. Üyelere, karşı tarafı anlamak için, ilk olarak doğru bir biçimde dinlemenin gerekli olduğu anlatılır. Bu konudaki etkinlikte, üyeler çift olurlar. Üye diğer üyeyi dinler; sonrasında dinlediğini gruba yeniden ifade eder. Konuşan üye, sonrasında kendi söylediği ile yeniden ifade edilen arasındaki tutarlılığı kontrol eder.

(6) Cinsiyet rolleri: Çok didaktik olmaksızın, cinsiyet rollerinin tartışılması ile kadınlar hakkında olumlu mesajların verildiği, denk ilişkilerin vurgulandığı sunum ve etkinlikler yapılabilir.

(7) Özsaygı: Üyelerin özsaygılarını desteklemek için bir "takdir etme etkinliği" yapılabilir. Bu etkinlikte, grup daire şeklindedir. Bir üye diğerine bir topu atarken, attığ takdir ettiği bir özelliğini söyler.

Wagar ve Rodway'in (1995) geliştirdiği grup çalışması programının hedefleri ise şöyledir: (1) Özsaygının artması, (2) Kendini koruma becerisi ile haklar ve destek sistemleri hakkında bilgi edinme, (3) Duyguları ifade, (4) Arkadaş ağının genişlemesi, (5) Bağımsız, yaşa-uygun karar verme, (6) Saldırganlığın azalması, (7) Sağlıklı olmayan durumlara hayır deme, (8) Anne ve baba kavga ettiğinde araya girmeyi reddetme.

\section{Kayıp ve Yas Sürecindeki Çocuklar}

Bir yakınını kaybetmiş bir çocuk, koşulları ve düzeyi değişebilmekle birlikte, kendisini fiziksel ve duygusal olarak destekleyen, koruyan ve model aldığı bir kişi ile içinde büyüyüp olgunlaşabileceği istikrarlı bir ev ortamını da kaybetmiş hissedebilir (Worden, 1996). Kayıp sonrasında yaşanan yasın çok bireysel bir süreç olduğu (Cohen ve Mannarino, 2011) bilinmekle birlikte, yas sürecinin tamamlanması ve olgunlaşması, çocuktaki ego fonksiyonlarının olgunlaşmasıyla mümkün olabilmektedir. Bunun nedeni, yas tutma kapasitesinin, birey ergenliğe ulaşıp tamamen farklılaşmadan kazanılamamasıdır (Wolfenstein, 1966; Worden, 1996).

Çeşitli yazarların sınıflamalarını dikkate alan Worden (1996), yas tutma aşamasında üzerinde çalışılıp başarıyla aşılması gereken basamakları şöyle sınıflandırmıştır:

1.Kayıp durumunun gerçekliğini kabul etme

2.Kayıp durumunun acısını ya da duygusal yönlerini yaşama

3.Kaybedilmiş kişinin olmadığı bir ortama uyum sağlama 
4.Ölen kişiyi kendi hayatına yeniden konumlandırma ve anımsama yollarını bulma

Yukarıda belirtildiği gibi, kayıp sonrası yas sürecinde, çocuklar, kendi zaman çerçevelerinde, kendi bireysel yollarıyla yaslarını yaşarlar ve sıklıkla, farklı zamanlarda daha önceki aşamalara geri dönerler. Bu süreçte, durumu yeniden yaşama aşaması dâhilinde, çocuk korkutucu ya da sıkıntı verici anılar ile karşılaşabilir. Bu nedenle kaçınma girişiminde bulunduğu aşamada, kaybettiği kişiyi anımsamak istemeyebilir. Bu süreçle bağlantılı olarak aşırı uyarılmış olma aşaması yaşanabilir ki, bu, çocuğun uyumakta zorluk yaşaması, öfkenin, fiziksel belirtilerin artmış olduğu bir aşamadır. Dolayısıyla çocuk, uyum sağlamasına engel olan bilişlere sahip olabilir ya da duygularını düzenlemekte güçlük çekebilir ve öğrenme sorunları yaşayabilir (Cohen ve Mannarino, 2011). Bu noktada Baker, Sedney ve Gross'un (1992), sonra yapılan grup çalışmalarına da yön gösteren görüşü vurgulanabilir. Yas, danışanın kayıpla bağlantılı bir farkındalık geliştirmesi, yas duygularını ifade etmesi ve başa çıkmak için yeni yolları öğrenmesi ile tamamlanıp aşılabilir (Finn, 2003).

\section{Kayıp ve Yas Sürecindeki Çocuklarla Yürütülen Gruplar}

Kayıp yaşamış çocuklarla yürütülen gruplarda, grubun ayrıntılı olarak yapılandırılması, güvenli ve destekleyici bir ortamın oluşmasını sağlamaktadır. Genel bir kural olarak, grup üyeleri ne kadar genç ise, yapılandırma o derecede gereklidir (Samide ve Stockton, 2002). Önerilen ilk modellerden biri olan Baker, Sedney ve Gross'un (1992) modelinde, üzerinde çalışılması gereken ilk görevler, bir kaybın yaşandığını kavrama ile temel güvenlik duygularını sağlamak iken, sonraki aşamada çocuklar, kaybın gerçekliği ve kalıcılığının kabul edilmesi aşamasına ulaşmaktadır. Son aşamada ise, bireyin kayıpla ilişkili olan yeni bir kimlik duygusunu kazanması, yeni ilişkilere açı olması ve yaşıyla uyumlu gelişimsel görevlere geri dönmesi görevleri söz konusudur (Finn, 2003).

Kayıp yaşamış çocuklarla grup çalışmalarının çeşitli avantajları (güvenli, destekleyici bir ortam, kayıp yaşamış olma konusunda yalnız olmadığını hissetme, konu ile bağlantılı öğrenme) olduğu gibi bazı dezavantajları da olabilmektedir. Örneğin, kayıp yaşantısına şiddetli ya da patolojik tepkide bulunan çocuklar söz konusu olduğunda grup çalışması pek uygun olmayabilmektedir. Ayrıca, akran desteği önemli olsa da, ev ortamında uyum sağlamayı engelleyen koşulların olması durumunda, grubun sağladığı destek de önemli oranda işlevsizleşebilmektedir (Worden, 1996).

Kayıp yaşayan çocuklarla yürütülen grup çalışmalarına sunulabilecek örneklerden bir diğeri, Samide ve Stockton'un (2002) çalışmasıdır. Bu çalışmada oturumlar, sırasıyla, (1) Duygular, (2) Ölüm eğitimi, (3) Anılar, (4) Değiş̧iklikler, (5)-(6) Yas eğitimi, (7) Rahatlamak, (8) Hoş̧̧akal demek, şeklinde sıralanmaktadır. Bu kapsamda, ölüm eğitimi oturumunda, çocuğun kafasında ölümle bağlantılı olarak ortaya çıkan her soruyu yanıtlamak amaçlanmaktadır. Anılar oturumunda, çocuklar, kaybettikleri kişiyle anıları hakkında konuşmaya teşvik edilmektedir. Değişiklikler oturumunda, çocukların, kayıp sonrası karşı karşıya kaldıkları değişiklikler üzerinde durmaları amaçlanmaktadır. Bu, çocuklardan, kayıp yaşanmadan önceki aileleri ile kayıp sonrası ailelerinin bir resmini yapıp, iki resim arasındaki farklılıkları ve aynı kalan unsurları tartışmalarını içermektedir. Yas eğitimi kapsamında, yasın aşamalarını, kısa ve yaşa uygun bir şekilde açıklamak bulunmaktadır. Rahatlama oturumunda, grup üyelerine, kaybettikleri kişiye hoşçakal demenin yollarını bulmaları ve rahatlama sürecini başlatmaları konusunda destek olunmaktadır. Bu sayede, çocukların, grup bittiğinde de bu süreci devam ettirmelerine katkı sağlayacak araçları edinmeleri amaçlanmaktadır. Hoşçakal oturumunda, grupta başarılanlara dair bir kutlamayı da içeren değerlendirme ve veda söz konusudur.

Çocukların kayıpla başa çıkmasında grupla danışmayı sanat ile bir arada yürüten Finn (2003) ise, başlangıç oturumundan sonuna kadar, üyeleri gruba sanat yoluyla dâhil etmektedir. İlk oturumda, üyelerden, bu gruba katılma nedenlerini ifade etmeleri için kendi portrelerini yapmaları istenmektedir. İkinci oturumda, üyelerin kayıpla bağlantılı duygularını araştırmaları desteklenmekte, üçüncü oturumda, insanların hatıralar, resimler ve müzik yoluyla nasıl hatırlanabileceğine odaklanılmaktadır. Dördüncü oturum, önceki oturumun bir devamı iken, beşinci oturumda, yas ile 
ortaya çıkan duygular ve hatıralarla başa çıkma yolları üzerinde çalışılmaktadır. Altıncı oturum, önceki oturumun devamı iken, yedinci oturumda, üyelerden, duygularını yansıtan üç resim çizmeleri istenir. Bu çalışmaya yönelik çeşitli boya ve materyaller hazır bulundurulur. Çocuklar resimlerini çizerken klasik müzik dinlerler ve bu esnada terapistler, aile ile ilgili konuları kapsayan bir tartışma başlatırlar. Sekizinci oturumda, konu, yasla başa çıkmanın bir yolu olarak diğer kişilerle bağlantı kurma ve iletişimdir. Yası ele almanın yapıcı ve yıkıcı yolları üzerinde durulur. Bu esnada resim yapmaya başlayan üyelerden, terapistler her beş dakikada, yerlerini değiştirmelerini ister. Bu etkinlik, grupta işbirliği düşüncesinin desteklenmesi amacıyla yapılırken, bu sayede üyeler başlangıçtaki çalışmalarına tekrar döndüklerinde çalışmalarını farklı bir bakış açısıyla görmüş olmaktadırlar. Son oturumda ise, yansıtmalar yapılıp yeni başlangıçlara vurgu yapılması ön planda olmaktadır.

Kayıp ve yas konusunda oluşturulan kapsamlı bir başka çalışma ise Bosna' da yaşanan savaşın ardından ergenlerle yürütülen grup psikoterapisi çalışmasıdır (Layne, Pynoos, Saltzman, Arslanagic, Black ve diğ., 2001). Yaklaşık yirmi oturum şeklinde düzenlenen çalışma dört modül halinde hazırlanmıştır.

Birinci modül, altı oturumdan oluşmakta ve akut sıkıntıyı azaltmak, grup birliğini kurmak ve sonraki yas-odaklı çalışmanın temelini oluşturmak üzere düzenlenmiştir. Başlangıçtaki terapötik görevler, gruba katılmanın önündeki engelleri tanımlama ve çözme, bireysel amaçları belirleme, travma sonrası stres, depresyon, yas belirtileri ve travmayı hatırlatan unsurlar hakkında psiko-eğitimi içermektedir. Sonrasında, nefes alma yoluyla gevşeme, düşünce-duygu düzenleme ve etkili destek arama konusunda beceri eğitimi gelmektedir. Bu aşamada temel amaç, kişinin başa çıkmak için kendi bireysel planını geliştirmesidir.

İkinci modül, sekiz ila on oturumdan oluşmakta ve travmatik yaşantıların terapötik bir şekilde işlenmesini içermektedir. Bu aşamada her üye travmatik yaşantısını grubun odağına getirmektedir. Sonrasında terapötik bir maruz kalma egzersizine katılmaktadırlar. Bireye travmatik yaşantıyı hatırlatan unsurlar üzerinde çalışılarak travmatik yaşantının öznel anlamının araştırılması, grubun güvenli ve destekleyici atmosferinde yapılmaktadır.

Üçüncü modülün amacı, kayıp karşısında uyum sağlayıcı yas tutmayı kolaylaştırmaktır. Bu kapsamda, yasla ilişkili yaşantıları ifade etmede kullanılabilecek bir sözcük dağarcığı oluşturmak, yas ve kaybı hatırlatan unsurlar hakkında psiko-eğitim yer almaktadır. Bu modül dört oturumdan oluşmaktadır. Dördüncü modül, üç oturumdan oluşmakta ve uyum sağlayıcı gelişimsel ilerleme, günlük hayata yapıcı bir şekilde katılım sağlama ile olumlu hayat amaçları düzenleyip ulaşmayı içermektedir.

Ülkemizde yapılan bir çalışma olarak, ebeveyn kaybı yaşamış olan 9-11 yaş grubundaki çocuklara yönelik hazırlanan dışavurumcu etkinliklere dayalı grupla psikolojik danışma programı bu açıdan ele alınabilir (Alıc1, 2010). Yazar, BASIC-Ph modeli kapsamında, kriz durumuna müdahale etme sürecini sekiz oturumluk grupla psikolojik danışma şeklinde yapılandırmış; oturumlar, tanışma ve ısınma aşaması, temel etkinlikler aşaması ile değerlendirme ve ayrılış aşamalarından oluşmuştur. Oturumlarda uygulanan etkinlikler travmatik duyguların dışavurumunu sağlarken aynı zamanda kişilerin krizle baş etme yöntemlerini güçlendirmeye yönelik planlanmıştır.

\section{Suça Sürüklenen Çocuklar}

Suça sürüklenen çocuklarla ilgili çalışan yazarlar, çocuğu bu şekilde nitelemenin belli koşulları gerektirdiği görüşünü ileri sürmektedir. Bu koşul, suça karışmanın, çocuk için bir yaşam stili olup olmaması durumudur. Eğer bir çocuk, herhangi bir ihtiyacını karşılamak için başka kişilerin haklarını ihlal etmişse, bir suç davranışını gerçekleştirmiştir (Glasser, 1965). Suça sürüklenen çocuk ise, yaşam stilini suç eylemleri üzerine kuran ve bu durumun farklı ortamlarda da süreklilik kazandığı bir olgudur (Ferrara, 1992).

Suça sürüklenen çocukların, başkalarının sınırlarını ihlal etmelerinden ayrı olarak kendilerinin de çeşitli kayıplar ve yoksunluklar yaşamış ve haklarının ihlal edilmiş olabildiği bildirilmektedir. Örneğin, ergen kız yükümlülerle yapılan bir çalışmada, sevilen birinin kaybı ya da o kişiye erişememe, fiziksel ya da cinsel istismar yaşantıları olduğu ortaya konulmuştur (Ryder, 2007). Başka 
bir görüşe göre, suça sürüklenen çocuklarda, psikopatik kişilik özellikleri, şiddet davranışıyla anlamlı bir şekilde ilişkilidir (Murrie, Cornell, Kaplan, McConville ve Levy-Elkon, 2004). Yükümlü erkek ergenlerle yapılan çalışmalarda, ruh sağlığı sorunlarına sahip olmanın suç davranışına erken başlama ile bağlantılı olduğu gösterilmiştir (Goethals, Willigenburg, Buitelaar ve Van Marle, 2008). Belirtilmesi gereken diğer bir nokta da, suça sürüklenen çocukların, duygularını ifade etme yeterliğinin, içinde bulundukları gelişim dönemine göre düşük düzeyde olmasıdır (Hessler ve Katz, 2010).

\section{Suça Sürüklenen Çocuklarla Yürütülen Gruplar}

Suça sürüklenen çocuklar için oluşturulan grup müdahalelerinden biri, "sınırla ve yönlendir" şeklinde özetlenebilmektedir. Buna göre, suça sürüklenen çocuklara yönelik bir grupla psikolojik danışma programı, sınırlı süre içerisinde etkili teknikleri kullanarak, çocuklarda istenmeyen davranışları azaltabilmelidir. Bu bakış açısına göre, tıbbi model, klinik sosyolojik model, kendineyardım yaklaşımı ve Rogeryen terapi, suça sürüklenen çocuklar özelinde etkisiz iken, model olma, net kurallar ve sonuçlar, pekiştirme miktarının net olması, başarılı olan yaklaşımlardır (Gendreau ve Ross, 1983). Sınırla ve yönlendir yaklaşımında iki ana amaç, gruba yön vermektedir. Birincisi her çocuğu birer birey olarak görmek, ikincisi grubu bir yaşam alanı olarak görmektir. Bu sayede çocuğun grupta kendisini bulması hedeflenmektedir. Grupta, her bireyin olumsuz, suçla bağlantılı davranışının azalması ve yerine olumlu, uygun davranışı kazanması hedeflenmekte; bu yöndeki çalışmalarda olumsuz davranışla ilişkili yüzleştirme, olumlu davranışın öğretilmesi ve pekiştirilmesi söz konusu olmaktadır (Ferrara, 1992). Değişmeye direnen çocuk ve ergenlerin olabilmesi muhtemeldir. Ancak Truax'ın (1971) çalışması, üyelerde oluşan negatif transferansın, olumlu terapötik yarar sağlama anlamına gelebileceğini bildirmektedir. Truax (1971), oluşan negatif transferansın, terapistin yetersiz empati, sıcaklık ve içtenliği olduğu anlamına gelmediğini ileri sürmektedir. Yazar, suça sürüklenen çocukların tipik olarak otorite figürleriyle zorluk yaşamakta olduklarını, terapisti de bir otorite figürü olarak algılamalarının söz konusu olabileceğini belirtmektedir.

Suça sürüklenen çocukların özellikle sosyal becerilerinin eksik olması fikrinden yola çıkan başka yazarlar da (Leeman, Gibbs ve Fuller, 1993), geliştirdikleri çok-bileşenli grup çalışması programında, grup üyelerine, hissedilen bir rahatsızlığı yapıcı bir biçimde ifade etme, kendisine kızgın olan biriyle iletişim kurma ve karşısındakinin duygularına yanıt verme gibi sosyal becerileri geliştirmeyi hedeflemişlerdir. Programın temel fikirlerinden biri, suça sürüklenen çocukların ahlaki gelişim konusunda yaşlarına uygun bir gelişim düzeyinde olmayabildikleridir. Bu noktadan hareketle, grup üyelerini yaşlarına uygun ahlaki gelişim düzeyine getirmek hedeflenmektedir. $\mathrm{Bu}$ program kapsamında, 8-10 kişiden oluşan gruplar, haftada beş gün, günde 1 veya 1,5 saat boyunca bir araya gelmektedirler. Böyle bir oturumda, bir üye kendi sorununu gruba getirmekte ve grup, üyeyi, kendi sorununu gruba getirdiği için kutlamaktadır.

"Suça sürüklenen çocuklarla nasıl bir grup çalışması olmalı" sorusuna ise, risk altındaki çocukların, eylem içeren süreçlerden daha fazla yararlanması olgusu dikkate alınarak yanıt verilebilir. Buna göre, risk altındaki çocuklar, içsel çatışmalarının sözel olarak analiz edilmesinden çok, eylem içeren süreçlerde yer almaya daha fazla güdülenmektedirler (Matousek ve Kroftova, 2003; Akt. Rezac, Kleckova ve Vaculik, 2012). Buradan hareketle, suça sürüklenen çocuklara yönelik hazırlanan programların, eylem içerme konusunda zengin olması, başarılı olma şansını arttırabilecektir.

Suça sürüklenen çocukların, katıldıkları bir grupta ne tür kazanımları olduğunu, çocukların kendilerine sorarak öğrenmeyi amaçlayan bir çalışmada, çocukların grup sürecinde kişisel bir büyüme ve empati düzeyinde bir artış gösterdikleri ortaya konulmuştur. Örneğin, bir katılımcı, grubun kendi üzerindeki etkisi sorulduğunda, "artık hep kendimi değil, diğerlerini de düşünüyorum" derken, diğer bir katılımcı ise, "yavaş yavaş, diğerlerinin ne söylediğini dinlemeye başladım, bu hoşuma gitti" demiştir. Başka bir katılımcı ise, "durumlara artık daha farklı yaklaşıyorum; daha önce benim için bir kavga sebebi olan şeyleri daha farklı çözüyorum" diyerek (Rezac, Kleckova ve Vaculik, 2012), grup sayesinde, problem çözme becerileri repertuvarının geliştiğini ifade etmiştir. 


\section{Tartışma, Sonuç ve Öneriler}

Çocuklar, herhangi bir risk altında bulunmasalar dahi, yüz yüze geldikleri gelişimsel zorluklar karşısında destek almaya gereksinim duyabilmektedirler. Bu destek, bireysel psikolojik danışma ile olduğu gibi, gruplar halindeki çocuklara ulaşabilen çalışmalarla da mümkündür. Çocuklara gruplar halinde ulaşabilmeyi hedefleyen üç çalışma türü, eğitimsel gruplar, danışma grupları ve terapi gruplarıdır (Shechtman, 2002). Bu grup türlerine yakından bakıldığında, özellikle danışma ve terapi gruplarının risk altındaki çocuklara destek olma konusunda işlevsel olabileceği düşünülmektedir.

Risk altındaki çocuklar, başlığın altına çeşitli alt grupların konumlandırılabileceği bir kavramdır. Bu başlık altında, savaş, afet gibi toplumsal nitelikteki travmaların olduğu kadar, herhangi bir saldırıya/istismara maruz kalmış olmak gibi bireysel travmaların mağduru olmak, şiddetin egemen olduğu bir evde yaşamak, sevdiği kişi ya da kişilerden koparılmış ya da suça sürüklenmiş bir çocuk olmak gibi çeşitli yaşantıları olan çocuklar incelenebilmektedir. Bu çalışma kapsamında, risk altındaki çocuklarla yürütülen grup çalı̧maları incelenmiş olup, risk altındaki çocuklar, ihmal ve istismar mağduru olan, kayıp ve yas yaşayan çocuklar ile suça sürüklenen çocuklar şeklinde tanımlanmıştır.

Ülkemizdeki ve uluslararası alan yazın incelendiğinde, risk altındaki çocuklarla yürütülen grup çalışmalarının içeriğinin çok yetersiz olmamakla birlikte geliştirilmeye ve derinleştirilmeye açık bir yapısı olduğu görülmektedir. Oluşturulan grup çalışma örneklerinin, hedef kitlelerine dair belli bazı ortak özellikleri yakalamış oldukları görülmüştür. Örneğin, ihmal ve istismar mağduru çocuklarla yürütülen grup çalışmalarında, mağdurun, grup süreci içerisinde, bu yaşantıya sahip olan tek kişinin kendisi olmadığının, yaşadıklarının sorumluluğunun kendisine ait olmadığının farkına varması, incelenen her çalışmada hedeflenen bir noktadır. Bu durumun, farklı kuramsal yönelimleri olsa da, yazarların hedefledikleri gruba özgü program hazırlama konusundaki duyarlılığının iyi bir göstergesi olduğu düşünülmektedir.

Kayıp ve yas sürecindeki çocuklarla yürütülen gruplar incelendiğinde, en dikkat çekici örneklerden biri, süreçte yaşanan duyguların, grupta yapılan ve deneyimlenen sanatsal etkinliklerle ifade edilmesinin desteklendiği (Finn, 2003) çalışma olmuştur. Özellikle söz ile anlatmakta zorluk çekilen duyguların alternatif dile getirme araçlarıyla ortaya çıkabilmesinin, ülkemizde yaşayan kayıp ve yas sürecindeki çocuklar söz konusu olduğunda işlevsel olabileceği düşünülmektedir. Alıcı'nın (2010) çalışması, bu konuda, ülkemizde yapılan bir grupla psikolojik danışma çalışması olarak öne çıkmaktadır. Özellikle büyük travmaların yaşandığı toplumlarda, bu konuda uzmanlaşmanın olabileceği, Bosna savaşının ardından meydana getirilen geniş çaplı grup çalışması programıyla gösterilmiştir (Layne ve diğ., 2001). Bu programın geniş çaplı olması, desteklenmesi hedeflenen grubun psikolojik anlamda ne denli derin ve çeşitli gereksinimlerinin olduğunun en önemli göstergesidir.

Suça sürüklenen çocuklarla yürütülen grup çalışmalarında öne çıkan ortak tema ise, destek verilmek istenen grubun biçimlendirilmesi gereken davranışlarının, grup sürecinde ele alınmasıdır. Çeşitli psikolojik ihtiyaçları konusunda yoksunluk yaşamış olabilen suça sürüklenen çocuğun, toplum tarafından kabul edilmeyen davranışları nedeniyle, olumsuz bir kısırdöngüye girerek, bu ihtiyaçlarını gidermekten gitgide uzaklaştığı görülebilmektedir. Bu döngüden çıkmanın yolu ise, çocuğun psikolojik ve sosyal gereksinimlerini karşılamanın daha kabul edilebilir yollarını grup sürecinde öğrenmesi olabilmekte ve grup çalışması sürecinde bu hedeflenmektedir.

$\mathrm{Bu}$ çalışma kapsamında incelenen neredeyse tüm çalışmaların ülkemiz dışında hazırlanmış olması dikkat çekicidir. Alıcı'nın (2010) çalışması, kayıp yaşayan çocuklara yönelik hazırlanmış olmasıyla, çoğaltılması gereken örneklerden biri olarak değerlendirilebilir. Gültekin'in (2020) çalışması, güncel çalışmalardan biri olarak koruma altındaki ergenlerle yapılan grup odaklı bir sosyal hizmet müdahalesidir. Yatkın'ın (2012) çalışması, suça sürüklenen 18-20 yaş gençlere yönelik olmasıyla bu çalışmanın kapsamı dışında görülmekte ve bu çalışmanın gelecekte 18 yaşın altındaki çocuklara yönelik olarak genişletilebileceği umut edilmektedir. Yapılan incelemenin sonucunda, risk altındaki çocuklara yönelik, ülkemizde yapılan çalışmaların sayısının çoğaltılması ve grupların 
özelliklerini dikkate alarak içeriklerin çeşitlendirilip derinleştirilmesi gerektiği düşünülmektedir. Bu konuda yapılacak çalışmaların, risk altında olarak nitelendirilmemiş çocuklarla yapılan çalışmalardan da (örn. Sancak, 2019; Kömeçoğlu, 2019) yararlanabileceği düşünülmektedir.

\section{Araştırma ve Yayın Etiği Beyanı}

Araştırma derleme çalışması olduğu için etik kurul başvurusu yapılmamıştır.

\section{Yazarların Makaleye Katkı Oranları}

Araştırma tek yazarlı olarak gerçekleştirilmiş ve araştırmanın tamamı sorumlu yazar tarafından tamamlanmiştır.

\section{Çıkar Beyanı}

Bu çalışma tek yazar tarafından tamamlanmıştır ve herhangi bir çıkar çatışması bulunmamaktadır."

\section{Kaynakça}

Alıc1, E. (2010). Dışavurumcu etkinliklere dayalı grupla psikolojik danışma programının ebeveyn kaybı yaşayan 9-11 yaş çocuklarının traoma sonrası stres düzeyine etkisi. Yayınlanmamış yüksek lisans tezi, Marmara Üniversitesi, Eğitim Bilimleri Enstitüsü.

Amerikan Psikiyatri Derneği (2000). Diagnostic and statistical manual of mental disorders. Washington DC.

Baker, J.E., Sedney, M.A. ve Gross, E. (1992). Psychological tasks for bereaved children, Amer. J. Orthopsychiat., 62(1), 105-116.

Brennan, S. (2006). Sibling incest within violent families: Children under 12 seeking nurture, Health Sociology Review, 15, 287-292.

Campbell, J.C. ve Lewandowski, L.A. (1997). Mental and physical health effects of intimate parter violence on women and children, Psychiatric Clinics of North America, 20(2), 353-374.

Chakhssi, F., de Ruiter, C. ve Bernstein, D.P. (2013). Early maladaptive cognitive schemas in child sexual offenders compared with sexual offenders against adults and nonsexual violent offenders: An exploratory study, Journal of Sexual Medicine, 10, 2201-2210.

Cohen, J.A. ve Mannarino, A.P. (2000). Incest. "Case Studies in Family Violence" içinde; Ed. R.T. Ammerman ve M. Hersen, 2. Bs.; ss. 209-229. Kluwer Academic/Plenum Publishers.

Cohen, J.A. ve Mannarino, A.P. (2011). Supporting children with traumatic grief: What educators need to know, School Psychology International, 32(2), 117-131.

Cui, L., Colasante, T., Malti, T., Ribeaud, D. ve Eisner, M.P. (2016). Dual trajectories of reactive and proactive aggression from mid-childhood to early adolescence: Relations to sensation seeking, risk taking, and moral reasoning, Journal of Abnormal Child Psychology, 44(4), 663-675.

deYoung, M. ve Corbin, B.A. (1994). Helping early adolescents tell: A guided exercise for traumafocused sexual abuse treatment groups, Child Welfare, 73(2), 141-154.

Dinkmeyer, D.C. ve Muro, J.J. (1979). Group counseling: Theory\&Practice. Wadsworth. 
Dodd, L.W. (2009). Therapeutic groupwork with young children and mothers who have experienced domestic abuse, Educational Psychology in Practice, 25(1), 21-36.

Elledge, L.C., Elledge, A.R., Newgent, R.A. ve Cavell, T.A. (2016). Social risk and peer vicitimization in elementary school children: The protective role of teacher-student relationships, Journal of Abnormal Child Psychology, 44(4), 691-703.

Ferrara, M.L. (1992). Group counseling with juvenile delinquents. Sage Publications.

Finn, C.A. (2003). Helping students cope with loss: Incorporating art into group counseling, The Journal for Specialists in Group Work, 28(2), 155-165.

Gendreau, P. ve Ross, R.R. (1983). Correctional treatment: Some recommendations for effective intervention, Juvenile \& Family Court Journal, 34(4), 31-40.

Glasser, W. (1965). Reality therapy: A new approach to psychiatry. Joanna Cotler Books.

Goethals, K., Willigenburg, L., Buitelaar, J. ve Van Marle, H. (2008). Behavior problems in childhood and adolescence in psychotic offenders: An exploratory study, Criminal Behaviour and Mental Health, 18(3), 153-165.

Green, A.H. (2000). Child neglect. “Case Studies in Family Violence” içinde; Ed. R.T. Ammerman ve M. Hersen, 2. Bs.; ss. 157-176. Kluwer Academic/Plenum Publishers.

Grusznski, R.J., Brink, J.C. ve Edleson, J.L. (1988). Support and education groups for children of battered women, Child Welfare, 67(5), 431-444.

Gültekin, N. (2020). Koruma ve bakım altında olan ergenlere yaşam becerileri kazandırılması "Grup odaklı sosyal hizmet müdahalesi örneği". Yayınlanmamış yüksek lisans tezi, Başkent Üniversitesi Sosyal Bilimler Enstitüsü.

Herman, J.L. (1992). Trauma and recovery. Harvard University Press.

Hessler, D.M. ve Katz, L.F. (2010). Brief report: Associations between emotional competence and adolescent risky behavior, Journal of Adolescence, 33(1), 241-246.

Jaffe, P., Wilson, S. ve Wolfe, D.A. (1986). Promoting changes in attitudes and understanding of conflict resolution among child witnesses of family violence, Canad. J. Behav. Sci., 18(4), 357366.

Jaffe, P., Wolfe, D., Wilson, S. ve Zak, L. (1986). Similarities in behavioral and social maladjustment among child victims and witnesses to family violence, Amer. J. Orthopsychiat., 56(1), 142-146.

Kendall-Tackett, K.A., Williams, L.M. ve Finkelhor, D. (1993). Impact of sexual abuse on children: A review and synthesis of recent empirical studies, Psychological Bulletin, 113, 164-180.

Kot, S., Landreth, G.L. ve Giordano, M. (1998). Intensive child-centered play therapy with child witnesses of domestic violence, International Journal of Play Therapy, 7(2), 17-36. 
Kömeçoğlu, S. (2019). Bir grup rehberliği programının 7. sını öğrencilerinin kişilerarası problem çözme becerileri üzerinde etkisinin incelenmesi. Yayınlanmamış yüksek lisans tezi, Yeditepe Üniversitesi Eğitim Bilimleri Enstitüsü.

Landreth, G.L. (1991). Play therapy: The art of the relationship. Accelerated Development Inc.

Layne, C.M., Pynoos, R.S., Saltzman, W.R., Arslanagic, B., Black, M., Savjak, N., Popovic, T., Durakovic, E., Music, M., Campara, N., Djapo, N. ve Houston, R. (2001). Trauma/grief-focused group psychotherapy: School-based postwar intervention with traumatized Bosnian adolescents, Group Dynamics: Theory, Research, and Practice, 5(4), 277-290.

Leeman, L.W., Gibbs, J.C. ve Fuller, D. (1993). Evaluation of a multi-component group treatment program for juvenile delinquents, Aggressive Behavior, 19, 281-292.

Levenson, J.S. ve Grady, M.D. (2016). The influence of childhood trauma on sexual violence and sexual deviance in adulthood, Traumatology, 22(2), 94-103.

Lopez, C. ve Bhat, C.S. (2007). Supporting students with incarcerated parents in schools: A group intervention, The Journal for Specialists in Group Work, 32(2), 139-53.

Lynch, M. (1999). Çocuk istismarı ve ihmali. "Çocuk İstismarı ve İhmali" içinde; Ed. E. Konanç, İ.Gürkaynak ve A. Egemen; ss. 1-8. Ankara: Çocuk İstismarını ve İhmalini Önleme Derneği.

McCloskey, L.A., Figueredo, A.J. ve Koss, M.P. (1995). The effects of systemic family violence on children's mental health, Child Development, 66, 1239-1261.

Morganett, R.S. (1990). Skills for living: Group counseling activities for young adolescents. Research Press.

Murrie, D.C., Cornell, D.G., Kaplan, S., McConville, D. ve Levy-Elkon, A. (2004). Psychopathy scores and violence among juvenile offenders: A multi-measure study, Behavioral Sciences and the Law, 22, 49-67.

Perkins, S.C., Smith-Darden, J., Ametrano, R.M. ve Graham-Bermann, S. (2014). Typologies of violence exposure and cognitive processing in incarcerated male adolescents, J. Fam. Viol., 29, 439-451.

Platt, S.B. (2016). Is physical abuse, neglect, or a combination of both more predictive of delinquent behavior in a high-risk population, Journal of Aggresion, Maltreatment ETrauma, 25(2), 145-163.

Rezac, P., Kleckova, K. ve Vaculik, M. (2012). Perception of juvenile delinquents of group therapy approaches, International Journal of Offender Therapy and Comparative Criminology, 57(8), 10091026.

Ryder, J.A. (2007). "I wasn't really bonded with my family": Attachment, loss and violence among adolescent female offenders, Critical Criminology, 15, 19-40.

Samide, L.L. ve Stockton, R. (2002). Letting go of grief, The Journal for Specialists in Group Work, 27(2), 192-204.

Sancak, S. (2019). Grup theraplay metodunun sinı ortamında uygulamasının okulöncesi çocukların sosyal becerileri ve problem davranışları üzerine etkisi. Yayınlanmamış yüksek lisans tezi, ODTÜ Sosyal Bilimler Enstitüsü. 
Shechtman, Z. (2002). Child group psychotherapy in the school at the threshold of a new millennium, Journal of Counseling and Development, 80, 293-299.

Shechtman, Z. ve Gluk, O. (2005). An investigation of therapeutic factors in children's groups, Group Dynamics: Theory, Research, and Practice, 9(2), 127-134.

Staff, J., Maggs, J.L., Cundiff, K. ve Evans-Polce, R.J. (2016). Childhood cigarette and alcohol use: Negative links with adjustment, Addictive Behaviors, 62, 122-128.

Thompson, E.H. (2011). The evolution of a children's domestic violence counseling group: Stages and processes, The Journal for Specialists in Group Work, 36(3), 178-201.

Truax, C.B. (1971). Degree of negative transference occuring in group psychotherapy and client outcome in juvenile delinquents, J. Clin. Psychol., 27(1), 132-136.

Wagar, J.M. ve Rodway, M.R. (1995). An evaluation of a group treatment approach for children who have witnessed wife abuse, Journal of Family Violence, 10(3), 295-306.

Wanlass, J., Moreno, J.K. ve Thomson, H.M. (2006). Group therapy for abused and neglected youth: Therapeutic and child advocacy challenges, The Journal for Specialists in Group Work, 31(4), 311326.

Wolfenstein, M. (1966). How is mourning possible?, The Psychoanalytic Study of the Child, 21, 93-123.

Worden, J.W. (1996). Children and grief: When a parent dies. The Guilford Press.

Yatkın, Ş. (2012). Grupla psikolojik danışma programının tutuklu ve hükümlü gençlerin sosyal becerilerine ve özsaygı düzeylerine ilişkin algılarına etkisi. Yayınlanmamış doktora tezi, Ankara Üniversitesi, Eğitim Bilimleri Enstitüsü.

\section{EXTENDED SUMMARY}

Children have to cope with the developmental challenges that they normally face while growing. These challenges are already exhausting to come over. But some children face more challenging facts arising from their family members or someone else. Facing the loss of a loved one when a person is a child is very difficult. A person cannot know what she/he would do with her/his overwhelming feelings. The grief she/he experiences is enormous. Besides that when a child has experienced abuse or neglect in the family, she/he can lose all the meaning devoted to the world, because of the hopelessness she/he experiences. Abuse and neglect can come up out of the family, from the people trusted by the family. Also a threat for the children is juvenile delinquency, emerging from the problems of the society playing an important role on the children.

These challenges children face are overwhelming so the situation for the child against the problem is difficult. She/he may feel little, weak or inefficacious. For these negative feelings that make a person hopeless for coming up her/his problems, group interventions may be helpful.

By group interventions the child would see that the only person that has experienced those difficult feelings is not herself/himself. Being not lonely is a strengthening factor for the child. Also, group interventions have some advantages compared to individual interventions. Group interventions make the single members a composite. This is called the power of the group. The group has a coherence and this is therapeutic. This group coherence becomes visible in group therapy and 
group counseling. In these groups, the leader makes the group conditions ready for enhancing healing. The group is a safe place for the members. No member can humiliate the other. Because in the beginning of the group, the leader has informed that this type of manners will not be wellcomed. So the members behave in a genuine manner towards each other. As they trust the safety, they give up the defenses. Even they become the healer for each other in the group coherence.

There are other types of group interventions too. Some groups are less deep emotionally. But they inform the members in a detailed way on a particular issue. These groups are beneficial too because knowledge about specific issues is very valuable in the life of a child. She/he may beware of asking the questions about the issue. The lack of information may result by an error or even by a guilt legally.

The children at-risk are clustered as being neglected and abused, having a loss of a loved one and juvenile delinquency. Being neglected or abused in childhood may arouse from the limitations of the parents. Besides that being the witness of family violence is one of the primary causes of abuse. Because of these experiences the child may learn that violence is a problem solving tool (Jaffe, Wilson and Wolfe, 1986). A group being run with the adolescent victims of abuse has the aim of providing emotional support, discussing on the developmental issues and enhancing resilience capacity (Wanlass, Moreno and Thomson, 2006). Besides that, the victim needs to know that she/he has no responsibility for the situation especially the violence. Also in the group process, the group discusses on particular emotions, like shame. The participants discuss how it feels to be ashamed, whether this feeling is necessary. Because feeling responsible for the situation makes the child more and more isolated and ashamed. And also she/he should learn how to make a planning for safety (Grusznski, Brink and Edleson, 1988). Besides, the child should learn about her/his rights and saying no when necessary (Wagar and Rodway, 1995).

For grief, the child should accept the reality about the loss, experience the feelings about the situation genuinely and then adapt to the reality and remember the loved one in a new way (Worden, 1996). For these steps, the child should be able to say goodbye (Samide and Stockton, 2002). For these goals, art can be added to the intervention (Finn, 2003).

There are inteventions for juvenile delinquency facts too. For these children, modeling, clear rules and facing the outcomes of their behaviors and also the reinforcement schedule should be explicit (Gendreau and Ross, 1983). And also the lack of social skills should be completed (Leeman, Gibbs and Fuller, 1993). The main rules of these interventions are "limit" and "guide" (Ferrara, 1992). These interventions should be act-oriented, because involving acts may be more motivating for the participants. The outcomes of the interventions revealed that the individuals who participated the group work developed empathy, approach the things that annoyed them in the past calmer, thinking before acting.

The interventions summarized here show that the group work with children at-risk has a therapeutic effect on individuals. These interventions include the examples from Turkey and out of Turkey. These interventions should be quantitatively and qualitatively more. The group work with any children can be beneficial and guiding for the group work with children at-risk. For this reason, the current works realized can be given as examples. The intervention of Alıc1 (2010) aimed to work with children who are suffering from grief. Also the studies of Sancak (2019) and Kömeçoğlu (2019) can give new ideas for the interventions that will be realized with children at-risk. 